\title{
An Electrochemical Study of Equilibria involving Di-calcium and Tri-calcium Phosphates ${ }^{1}$
}

\author{
H. Hoshino ${ }^{2}$, M. Iwase ${ }^{3}$ and A. McLean ${ }^{4}$ \\ Department of Energy Science and Technology \\ Kyoto University \\ Kyoto 606-8501, Japan
}

(Received March 11, 2004 final form March 24, 2004 )

\begin{abstract}
An electrochemical technique incorporating a solid oxide galvanic cell was employed at temperatures between 1,423 and $1,523 \mathrm{~K}$ to obtain the free energy change for the reaction:

$$
2 \mathrm{Ca}_{3} \mathrm{P}_{2} \mathrm{O}_{8}(\mathrm{~s})+\mathrm{P}_{2}(\mathrm{~g})+(5 / 2) \mathrm{O}_{2}(\mathrm{~g})=3 \mathrm{Ca}_{2} \mathrm{P}_{2} \mathrm{O}_{7}(\mathrm{~s})
$$

The cell used for this study can be represented by the formulation:

$$
\begin{aligned}
& +\mathrm{Mo} / \mathrm{Mo}+\mathrm{MoO}_{2} / \mathrm{ZrO}_{2}(\mathrm{MgO}) / \\
& \{\mathrm{Cu}-\mathrm{P}\} \text { alloy }+\mathrm{Ca}_{3} \mathrm{P}_{2} \mathrm{O}_{8}+\mathrm{Ca}_{2} \mathrm{P}_{2} \mathrm{O}_{7} / \mathrm{Mo}(
\end{aligned}
$$

The results obtained can be expressed in terms of the following equation:

$$
\Delta G^{\circ} \mathrm{J} \mathrm{mol}{ }^{-1}=-1,896,000+449.8(T / K) \pm 15,900
$$

By combining these results with data from the literature, values were calculated for the activity of $\mathrm{P}_{2} \mathrm{O}_{5}$ in equilibrium with the two solid phases di-calcium and
\end{abstract}

tri-calcium phosphates:

$$
\begin{aligned}
& 2 \mathrm{Ca}_{3} \mathrm{P}_{2} \mathrm{O}_{8}(\mathrm{~s})+\mathrm{P}_{2} \mathrm{O}_{5}(\mathrm{l})=3 \mathrm{Ca}_{2} \mathrm{P}_{2} \mathrm{O}_{7}(\mathrm{~s}) \\
& \Delta G^{\circ} / \mathrm{J} \mathrm{Imol} \mathrm{I}^{-1}=-361,500-56.4(T / \mathrm{K}) \\
& \log a_{P_{2} O_{5}}=-2.950-18,840 /(T / \mathrm{K})
\end{aligned}
$$

This has important implications in the design and selection of slags for the dephosphorization of hot metal during iron and steelmaking processes.

\section{FOREWORD}

This paper was prepared in tribute to the memory of our good friend Professor James Makoto Toguri, who for over forty years published extensively and made major contributions to the field of high temperature physical chemistry of metallurgical reactions. Working within the University of Toronto, Professor Toguri's primary objective was always to provide an environment where students would develop new knowledge and understanding of the fundamental aspects of their discipline, and perhaps most

\footnotetext{
I All inquiries relating to this paper should be made to Professor M. Iwase, Department of Energy Science and Technology, Kyoto University, Kyoto 606-8501, Japan, iwase@namihei.mtl.kyoto-u.ac.jp

${ }^{2}$ Formerly, PhD Student, Department of Metallurgy, Kyoto University, Kyoto 606-8501, Japan, now with Research Institute of Industrial Science, Osaka Prefecture, Osaka.

${ }^{3}$ Professor, Department of Energy Science and Technology, Kyoto University, Kyoto 606-8501, Japan.

${ }^{4}$ Invited Professor, Department of Energy Science and Technology, Kyoto University, Kyoto 606-8501, Japan, Professor Emeritus, Department of Materials Science and Engineering, University of Toronto, Toronto, Canada, M5S $3 \mathrm{E} 4$.
} 
significantly, come to appreciate the vital importance of people and of personal interactions. It is therefore not at all surprising that many of his former students now occupy leadership positions within industrial organizations and academic institutions throughout the world. This is surely the greatest testimonial to the life and work of a great teacher, outstanding scientist and brilliant engineer who throughout his professional career was a friend to so many.

\section{INTRODUCTION}

By using an electrochemical technique incorporating magnesia-stabilized zirconia, the authors $/ 1,2 /$ have previously determined the free energy changes for the reactions:

$$
\begin{aligned}
& 4 \mathrm{CaO}(\mathrm{s})+\mathrm{P}_{2}(\mathrm{~g})+(5 / 2) \mathrm{O}_{2}(\mathrm{~g})=\mathrm{Ca}_{4} \mathrm{P}_{2} \mathrm{O}_{5}(\mathrm{~s}) \\
& 3 \mathrm{Ca}_{4} \mathrm{P}_{2} \mathrm{O}_{9}+\mathrm{P}_{2}(\mathrm{~g})+(5 / 2) \mathrm{O}_{2}(\mathrm{~g})=4 \mathrm{Ca}_{3} \mathrm{P}_{2} \mathrm{O}_{8}(\mathrm{~s})
\end{aligned}
$$

This work has now been extended to measurements of the free energy change for the following reaction:

$$
\begin{aligned}
& 2 \mathrm{Ca}_{3} \mathrm{P}_{2} \mathrm{O}_{8}(\mathrm{~s})+\mathrm{P}_{2}(\mathrm{~g})+(5 / 2) \mathrm{O}_{2}(\mathrm{~g}) \\
& =3 \mathrm{Ca}_{2} \mathrm{P}_{2} \mathrm{O}_{7}(\mathrm{~s})
\end{aligned}
$$

In the present study, mixtures of $\mathrm{Ca}_{7} \mathrm{P}_{2} \mathrm{O}_{8}+\mathrm{Ca}_{2} \mathrm{P}_{2} \mathrm{O}_{7}$ were brought into equilibrium with $\{\mathrm{Cu}-\mathrm{P}\}$ liquid alloys at temperatures between $1423 \mathrm{~K}$ and $1523 \mathrm{~K}$. The equilibrium oxygen partial pressures were determined with the aid of a solid state galvanic cell incorporating magnesia-stabilized zirconia and a $\mathrm{Mo}+\mathrm{MoO}_{2}$ reference electrode. Figure 1 shows the phase diagram of the system $\mathrm{CaO}+\mathrm{P}_{2} \mathrm{O}_{5} / 3 /$. The hatched area of Figure $\mathrm{I}$ indicates the bulk compositions of the $\mathrm{Ca}_{3} \mathrm{P}_{2} \mathrm{O}_{8}$ $+\mathrm{Ca}_{2} \mathrm{P}_{2} \mathrm{O}_{7}$ mixture used for the experiments. At temperatures below $1561 \mathrm{~K}$, the mixture consists of the two solid phases.

\section{EXPERIMENTAL ASPECTS}

Tri-calcium phosphate, $\mathrm{Ca}_{3} \mathrm{P}_{2} \mathrm{O}_{8}$, was commercially available from Nakarai Tesuque Corp. Di-calcium

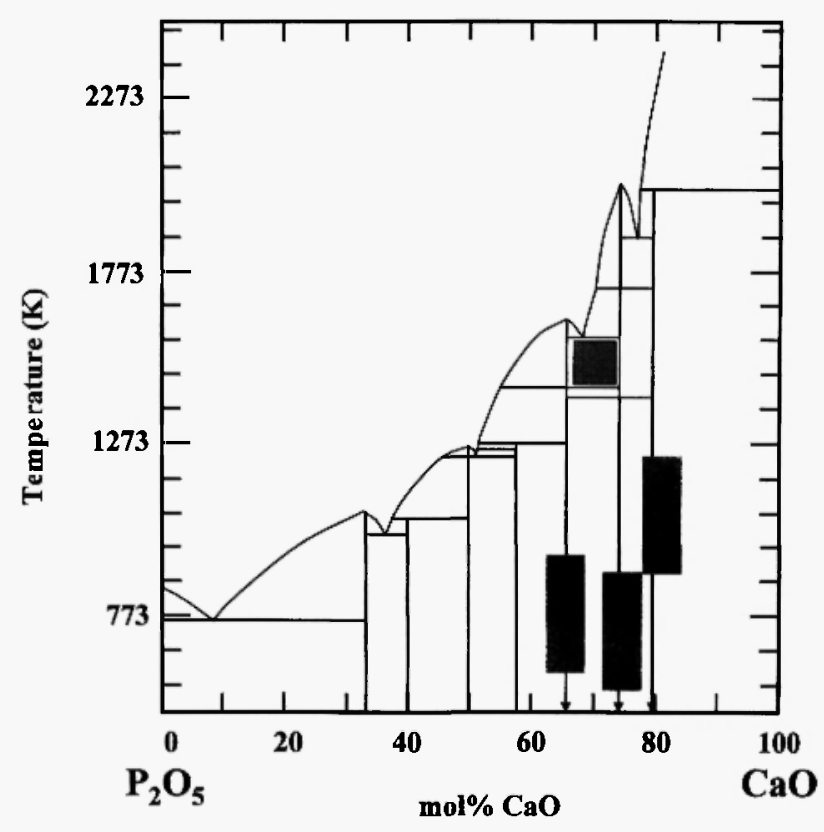

Fig. 1: Phase diagram of the system $\mathrm{CaO}-\mathrm{P}_{2} \mathrm{O}_{5}$.

phosphate, $\mathrm{Ca}_{2} \mathrm{P}_{2} \mathrm{O}_{7}$, was prepared by heating calcium hydro-phosphate di-hydrate, $\mathrm{CaHPO}_{4} \cdot 2 \mathrm{H}_{2} \mathrm{O}$, very slowly to $1273 \mathrm{~K}$ in a platinum crucible at ambient atmosphere. Heating was continued until there was no further change in weight of the product. X-ray diffraction analysis confirmed the existence of only the expected phase.

The details of the experimental apparatus and procedures have been described elsewhere $14 /$. The experimental apparatus is shown schematically in Figure 2. About $200 \mathrm{~g}$ of high-purity, oxygen free copper and copper phosphide, $\mathrm{Cu}_{3} \mathrm{P}$, were melted in a molybdenum crucible of $38 \mathrm{~mm}$ o.d., $33 \mathrm{~mm}$ i.d. and $60 \mathrm{~mm}$ length, together with pellets of $\mathrm{Ca}_{3} \mathrm{P}_{2} \mathrm{O}_{8}+$ $\mathrm{Ca}_{2} \mathrm{P}_{2} \mathrm{O}_{7}$ mixture under a stream of purified argon inside a $\mathrm{SiC}$ resistance furnace, which was equipped with a mullite reaction tube of $70 \mathrm{~mm}$ o.d., $60 \mathrm{~mm}$ i.d. and $1.000 \mathrm{~mm}$ length. The gas purification train consisted of silica-gel, magnesium perchlorate, phosphorus pentoxide and magnesium chips held at $873 \mathrm{~K}$. In order to further deoxidize the argon gas, a column of titanium granules was placed inside a magnesia crucible below the crucible containing the copper, at a position where the temperature was 1,050 to $1,150 \mathrm{~K}$.

The electrochemical half-cell. $\mathrm{Mo} / \mathrm{Mo}+\mathrm{MoO}_{2} /$ $\mathrm{ZrO}_{2}(\mathrm{MgO})$, shown in Figure 2, consisted of a zirconia 


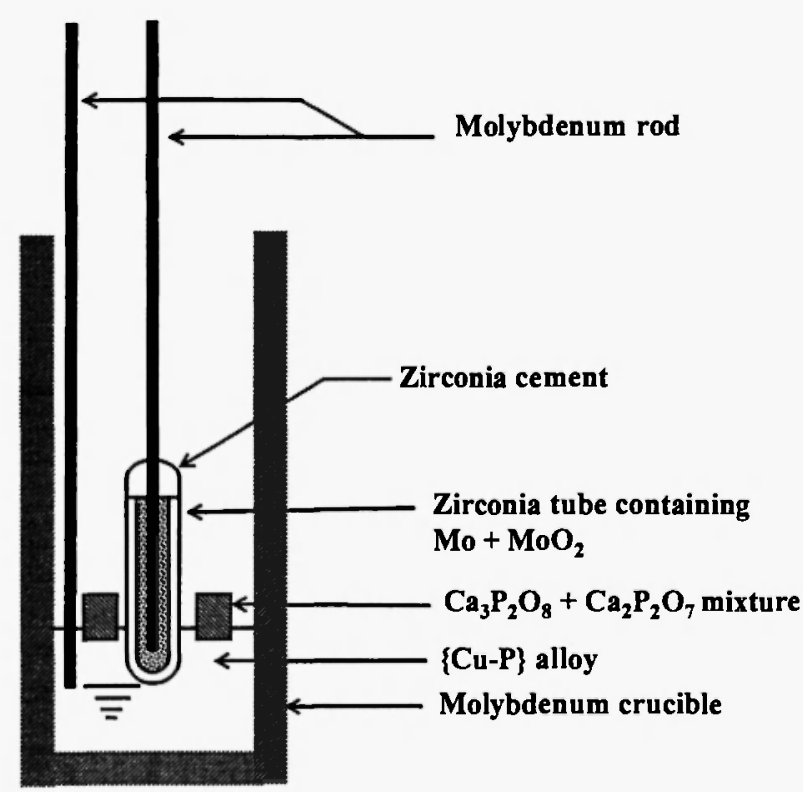

Fig. 2: Experimental setup.

tube and a two-phase mixture of 4 parts Mo and 1 part $\mathrm{MoO}_{2}$ by weight. The details of this zirconia cell have been reported previously $15 \%$ Iso-statically pressed zirconia tubes, closed at one end and stabilized by $9 \mathrm{~mol}$ $\%$ of MgO. were supplied by Nikkato Corp. These tubes had an i.d. of $4 \mathrm{~mm}$, an o.d. of $6 \mathrm{~mm}$ and a length of $50 \mathrm{~mm}$. A molybdenum rod $3 \mathrm{~mm}$ in diameter was used as an electrical lead to the reference electrode and was fixed at the top of the zirconia tube by means of zirconia cement (Sumitomo Chemical Industry Co. Ltd.. SUMICERAM S-301). A second molybdenum rod 3 $\mathrm{mm}$ in diameter served as the electrical contact to the outer electrode of the zirconia probe. Dissolution of molybdenum in liquid copper was negligibly small.

The experimental procedure consisted of measuring the open-circuit emf of the solid-state oxygen probe, and sampling the liquid $\{\mathrm{Cu}-\mathrm{P}\}$ alloys for analysis of phosphorus. The cell potentials generated were measured via the two molybdenum rods and monitored on a strip-chart recorder of $2 \mathrm{M} \Omega$ internal impedance with an accuracy of $\pm 0.1 \mathrm{mV}$. The emt values could also be read on a digital voltmeter of $100 \mathrm{M} \Omega$ input resistance with an accuracy of $\pm 0.01 \mathrm{mV}$. The emf measurements were continued until the reproducibilities were confirmed.

After stable cell potentials were obtained, 10 to $20 \mathrm{~g}$ samples were withdrawn from the copper melt by means of a silica sampling tube of $3 \mathrm{~mm}$ i.d. Chemical analysis of phosphorus in copper was made using the procedure described elsewhere $/ 6 /$. The concentration of phosphorus in molten copper was changed by the addition of $\mathrm{Cu}_{3} \mathrm{P}$ or oxygen free copper. After these additions. a time period of 24 to 168 hours was required to establish equilibrium. Temperatures were measured with a Pt-PtRh13 thermocouple placed alongside the high-purity alumina crucible, and controlled to $\pm 2 \mathrm{~K}$ by using a control thermocouple and PID-type thermocouple regulator. Experiments were conducted at 1423,1473 and $1523 \mathrm{~K}$.

\section{EXPERIMENTAL RESULTS AND DISCUSSION}

The experimental results are summarized in Table 1. The equilibrium oxygen partial pressures of the liquid alloy, $P_{O_{2}}$, can be calculated by the following equation:

$$
E=\frac{R T}{F}-\ln \frac{P_{O_{2}}(\text { ref.. })^{1 / 4}+P_{e}^{1 / 4}}{P_{O_{2}}(\text { alloy })^{1 / 4}+P_{e}^{1 / 4}}
$$

where $E$ is the cell voltage, $R$ is the gas constant, $T$ is temperature, $F$ is the Faraday constant, and $P_{e}$ is the oxygen partial pressure at which the ionic and n-type electronic conductivities are equal. Values for this parameter for the magnesia-stabilized zirconia tubes used in this study have been reported elsewhere $/ 7 /$ :

$$
\log (P e / \mathrm{atm})=+20.40-6.45 \times 10^{4} /(T / \mathrm{K})
$$

The oxygen partial pressure at the reference electrode, $\mathrm{Mo}+\mathrm{MoO}_{2}, \mathrm{PO}_{2}$ (ref.), was calculated from the authors' previous result $/ 8$ :

$$
\log \left\{P_{O_{2}}(\text { ref. }) / \mathrm{atm}\right\}=+8.84-3.01 \times 10^{4} /(T / \mathrm{K})(6)
$$

The equilibrium reaction underlying the emf measurements is expressed by:

$$
\begin{aligned}
& 2 \mathrm{Ca}_{3} \mathrm{P}_{2} \mathrm{O}_{8}(\mathrm{~s})+2 \mathrm{P}(1 \% \text { in } \mathrm{Cu})+(5 / 2) \mathrm{O}_{2}(\mathrm{~g}) \\
& =3 \mathrm{Ca}_{2} \mathrm{P}_{2} \mathrm{O}_{7}(\mathrm{~s}) \\
& \log K(7)=-2 \log h_{r^{\prime}}-(5 / 2) \log P_{O_{2}}
\end{aligned}
$$


Table 1

Experimental results.

\begin{tabular}{|c|c|c|c|c|c|c|}
\hline & & \multicolumn{2}{|c|}{$E / \mathrm{mV}$} & {$[\% P]$} & $\log P_{O_{2}}$ & $\log a_{P_{2} O_{5}}$ \\
\hline $61-1$ & 1523 & 54.4 & \pm 0.2 & $0.012 \pm 0.000$ & $-11.64 \pm 0.01$ & $-15.26 \pm 0.04$ \\
\hline $61-2$ & 1523 & 55.3 & \pm 0.5 & $0.012 \pm 0.000$ & $-11.65 \pm 0.02$ & $-15.34 \pm 0.05$ \\
\hline $61-3$ & 1523 & 49.2 & \pm 0.1 & $0.009 \pm 0.000$ & $-11.57 \pm 0.01$ & $-15.36 \pm 0.02$ \\
\hline $61-4$ & 1523 & 75.9 & \pm 0.7 & $0.022 \pm 0.000$ & $-11.93 \pm 0.03$ & $-15.48 \pm 0.04$ \\
\hline $61-5$ & 1523 & 74.3 & \pm 1.2 & $0.024 \pm 0.000$ & $-11.91 \pm 0.04$ & $-15.33 \pm 0.06$ \\
\hline $61-6$ & 1523 & 74.9 & \pm 0.5 & $0.024 \pm 0.000$ & $-11.92 \pm 0.02$ & $-15.36 \pm 0.04$ \\
\hline $61-7$ & 1523 & 101.3 & \pm 3.2 & $0.106 \pm 0.003$ & $-12.27 \pm 0.11$ & $-14.96 \pm 0.13$ \\
\hline \multirow[t]{2}{*}{$61-8$} & 1523 & 140.1 & \pm 2.8 & $0.339 \pm 0.004$ & $-12.78 \pm 0.10$ & $-15.24 \pm 0.11$ \\
\hline & & & & & $\log a_{P_{2} O_{5} \text { (average) }}$ & $-15.29 \pm 0.15$ \\
\hline $62-3$ & 1473 & 71.0 & \pm 1.2 & $0.008 \pm 0$ & $-12.56 \pm 0.04$ & $-16.49 \pm 0.08$ \\
\hline $62-6$ & 1473 & 124.8 & \pm 1.1 & $0.100 \pm 0.003$ & $-13.30 \pm 0.04$ & $-16.10 \pm 0.07$ \\
\hline $62-7$ & 1473 & 121.2 & \pm 2.4 & $0.119 \pm 0.006$ & $-13.25 \pm 0.09$ & $-15.83 \pm 0.13$ \\
\hline $62-9$ & 1473 & 120.0 & \pm 2.8 & $0.140 \pm 0.004$ & $-13.24 \pm 0.10$ & $-15.65 \pm 0.12$ \\
\hline $63-1$ & 1473 & 74.9 & \pm 0.5 & $0.049 \pm 0.003$ & $-12.62 \pm 0.02$ & $-15.00 \pm 0.08$ \\
\hline $63-2$ & 1473 & 88.7 & \pm 0.6 & $0.028 \pm 0.001$ & $-12.81 \pm 0.03$ & $-15.98 \pm 0.04$ \\
\hline $63-5$ & 1473 & 105.2 & \pm 3.5 & $0.087 \pm 0.004$ & $-13.05 \pm 0.12$ & $-15.59 \pm 0.16$ \\
\hline \multirow[t]{2}{*}{$63-6$} & 1473 & 112.7 & \pm 2.0 & $0.097 \pm 0.002$ & $-13.14 \pm 0.07$ & $-15.71 \pm 0.09$ \\
\hline & & & & & $\log a_{P_{2} O_{5}}$ (average) & $-15.79 \pm 0.43$ \\
\hline $66-2$ & 1423 & 60.1 & \pm 0.7 & $0.009 \pm 0.000$ & $-13.16 \pm 0.03$ & $-16.23 \pm 0.03$ \\
\hline $66-4$ & 1423 & 55.7 & \pm 2.4 & $0.009 \pm 0.000$ & $-13.10 \pm$ & \pm 0.11 \\
\hline $66-5$ & 1423 & 72.1 & \pm 0.6 & $0.014 \pm 0.000$ & $-13.33 \pm$ & \pm 0.05 \\
\hline $66-6$ & 1423 & 75.7 & \pm 2.7 & $0.018 \pm 0.001$ & $-13.38 \pm$ & \pm 0.16 \\
\hline $64-3$ & 1423 & 68.0 & \pm 1.0 & $0.014 \pm 0.001$ & $-13.27 \pm$ & \pm 0.07 \\
\hline $64-4$ & 1423 & 74.5 & \pm 1.3 & $0.018 \pm 0.001$ & $-13.37 \pm$ & \pm 0.80 \\
\hline \multirow[t]{2}{*}{$64-5$} & 1423 & 103.2 & \pm 1.7 & $0.065 \pm 0.001$ & $-13.78 \pm 0.07$ & -16.05 \\
\hline & & & & & $\log a_{P_{2} O_{5}}$ (average) & $-16.16 \pm 0.08$ \\
\hline
\end{tabular}

where $h_{p}$, is the Henrian activity of atomic phosphorus referred to the 1 wt pct solution in liquid copper. At phosphorus concentrations below Ipct by weight, the solution of phosphorus in liquid copper obeys Henry's law $/ 9 /$ and $h_{p}=[\% P]_{(u}$. Hence, a logarithmic plot of $P_{\mathrm{O}_{2}}$ against phosphorus content in liquid copper, $[\% P]_{C u}$, should be linear with a slope of $-4 / 5$. A plot of this form is given in Figure 3. As shown in this diagram, the relation is linear and the slope is very close to $-4 / 5$. The equilibrium constant, $K(7)$, can now be calculated from the relation:

$$
\log K(7)=-2 \log [\% P]_{c u}-(5 / 2) \log P_{O_{2}}
$$

The values for $\log K(7)$ are plotted against reciprocal temperature in Figure 4, and the following relationship is obtained:

$$
\begin{aligned}
& \log K(7)=86,000 /(T / \mathrm{K})-23.44 \\
& \Delta G^{\prime \prime}(7) / \mathrm{J} \cdot \mathrm{mol}^{-1}=-1,646,000 \\
& +448.7(T / \mathrm{K}) \pm 4,900
\end{aligned}
$$

The free energy change for the dissolution of gaseous diatomic phosphorus in liquid copper at infinite dilution referred to I pct by weight has been determined 


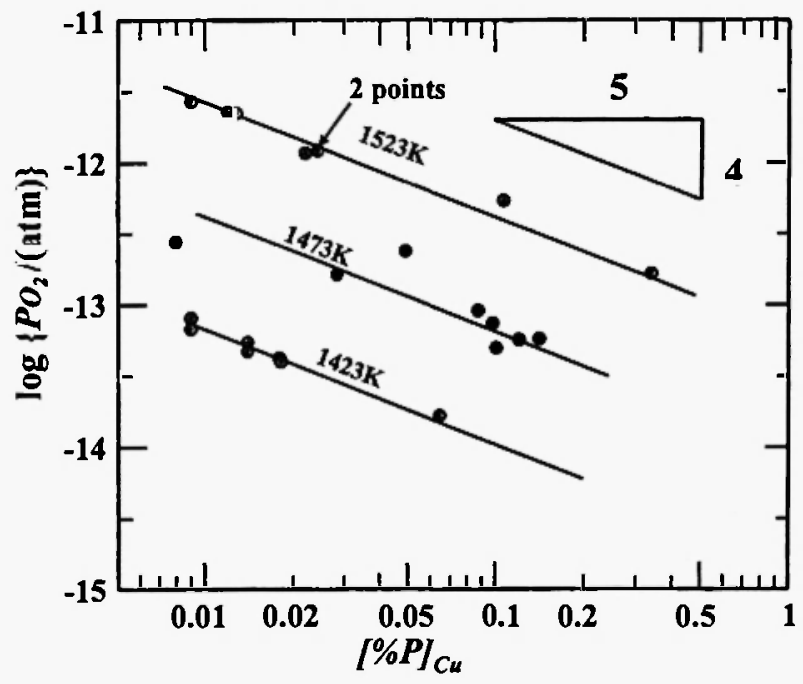

Fig. 3: Relationship between oxygen potential and phosphorous content of liquid copper at 1423 , 1473 and $1523 \mathrm{~K}$.

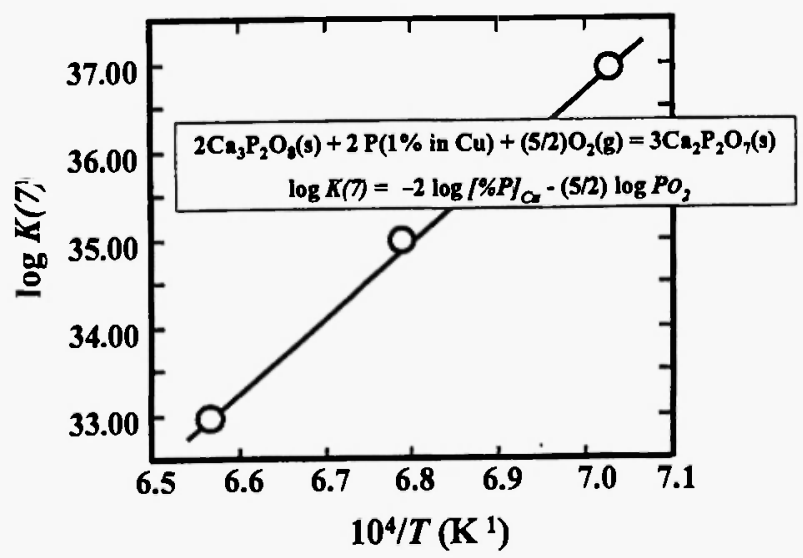

Fig. 4: Effect of temperature on the equilibrium constant for the reaction: $2 \mathrm{Ca}_{3} \mathrm{P}_{2} \mathrm{O}_{8}(\mathrm{~s})+2$ $\mathrm{P}(1 \%$ in $\mathrm{Cu})+(5 / 2) \mathrm{O}_{2}(\mathrm{~g})=3 \mathrm{Ca}_{2} \mathrm{P}_{2} \mathrm{O}_{7}(\mathrm{~s})$.

by the present authors $/ 9 /$ :

$(1 / 2) P_{2}(g)=P(1 \%$ in $\mathrm{Cu})$

$A\left(G^{\circ}(12) / \mathrm{J} \mathrm{mol}^{-1} \cdots-125,000\right.$

$+0.54(T / \mathrm{K}) \pm 5.500$

By combining equations [10] and [12], it follows:

$2 \mathrm{Ca}_{3} \mathrm{P}_{2} \mathrm{O}_{8}(\mathrm{~s})+\mathrm{P}_{2}(\mathrm{~g})+(5 / 2) \mathrm{O}_{2}(\mathrm{~s})$

$=3 \mathrm{Ca}_{3} \mathrm{P}_{2} \mathrm{O}_{7}(\mathrm{~s})$
$\Delta G^{\circ}(/ 4) / \mathrm{J} \cdot \mathrm{mol}^{-1}=-1,896,000+449.8(T / \mathrm{K})$

$\pm 15,900$

For the reaction expressed as:

$\mathrm{P}_{2}(\mathrm{~g})+(5 / 2) \mathrm{O}_{2}=\mathrm{P}_{2} \mathrm{O}_{5}(\mathrm{l})$

Turkdogan and Pearson $/ 10 /$ have given the following relationship:

$\Delta G^{\circ}(/ 6) / \mathrm{J} \quad \mathrm{mol}^{-1}=-1,534,500+506.2(T / \mathrm{K})$

By combining reactions (14) and (16), we have:

$$
\begin{aligned}
& 2 \mathrm{Ca}_{3} \mathrm{P}_{2} \mathrm{O}_{8}(\mathrm{~s})+\mathrm{P}_{2} \mathrm{O}_{5}(\mathrm{l})=3 \mathrm{Ca}_{2} \mathrm{P}_{2} \mathrm{O}_{7}(\mathrm{~s}) \\
& \Delta G^{\circ}(18) / \mathrm{J} \cdot \mathrm{mol}^{-i}=-361,500-56.4(T / \mathrm{K})
\end{aligned}
$$

$$
\log K(18)=-\log a_{P_{2} O_{5}}\left(C_{3} P+C_{2} P\right)=2.950
$$$$
+18.840 /(T / \mathrm{K})
$$

In Figure 5, the present values for $a_{P,} O_{-} / C_{3} P+$ $C_{2} P$ ) are compared with data from the literature for $a_{P_{2} O_{3}}\left(C+C_{1} P\right)$ and $a_{P, O_{j}}\left(C_{1} P+C_{3} P\right)$. As would be expected. the activity of $\mathrm{P}_{2} \mathrm{O}_{5}$ increases as the $\mathrm{CaO}$ content of the mixed oxide phase decreases. It is noteworthy that the increase in activity in shifting from the $C_{4} P+C_{3} P$ system to the $C_{3} P+C_{2} P$ system, about nine orders of magnitude, is substantially greater than that found when shifting from the $C+C_{\downarrow} P$ to the $C_{\downarrow} P+$ $C_{3} P$ system, which is between one and two orders of magnitude. This is in accord with the view that in the more basic systems $C+C_{4} P$ and $C_{4} P+C_{3} P$, the phosphate ions exist in the melt as $\mathrm{PO}_{4}{ }^{33}$ monomers with a relatively low activity, whereas in the less basic system, $C_{3} P+C_{2} P$. the phosphate ions will exist as $\mathrm{P}_{2} \mathrm{O}_{7}{ }^{4 \cdot}$ dimers with significantly greater activity. This has important implications in the design and selection of slags that will provide an appropriate environment with a low activity of $\mathrm{P}_{2} \mathrm{O}_{5}$ for the dephosphorization of hot metal during iron and steelmaking processes.

\section{REFERENCES}

I. M. Iwase, H. Fujiwara, E. Ichise, H. Kitaguchi and K. Ashida, Transactions of The Iron and Steel 


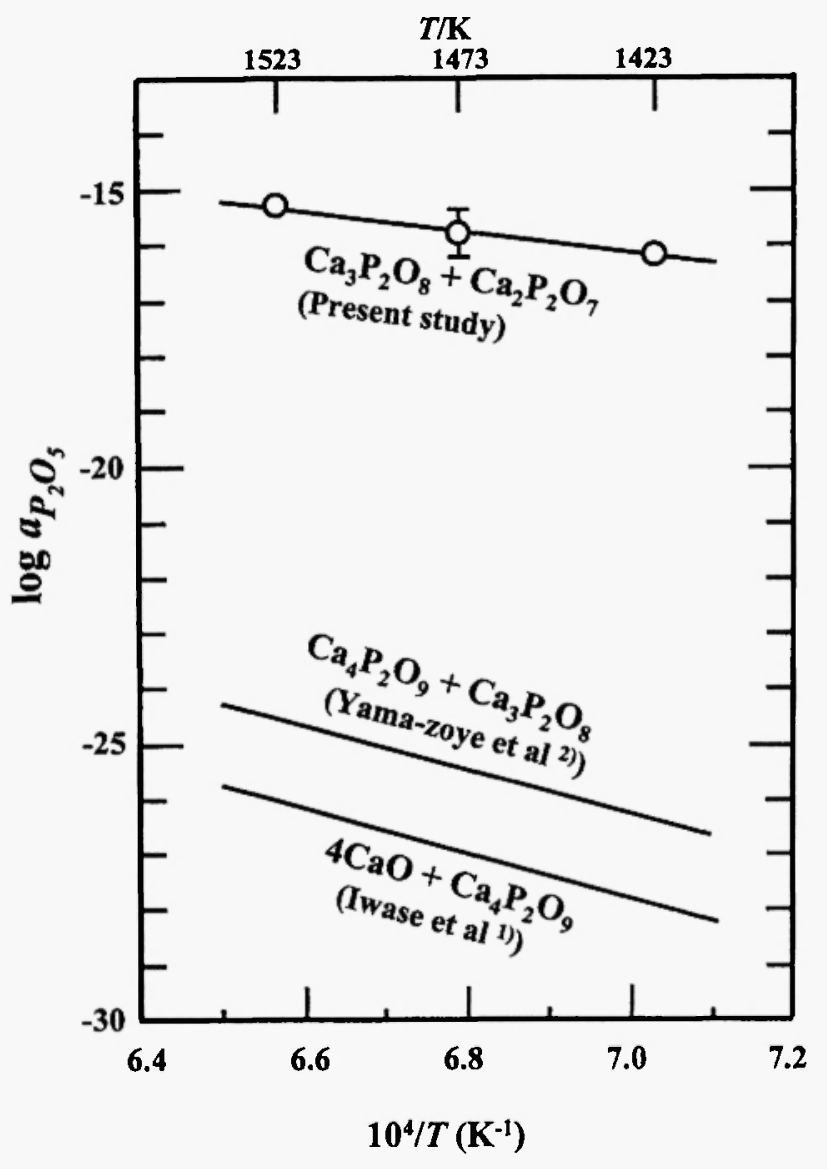

Fig. 5: Comparison of the activities of $\mathrm{P}_{2} \mathrm{O}_{5}$ for equilibrium with different lime phosphate compounds.
Socien of A.I.M.E. 11, 31-38 (1990), and also in Iron and Steelmaker, 16 (4), 45-51 (1989).

2. H. Yama-zoye, H. Fujiwara, E. Ichise and $M$. Iwase. Transactions of The Iron and Steel Society of .4.I.M.E. 13, 41-46 (1992), and also in Iron and Siedmaker, 18. 75-80 (1991).

3. G. Troemel and W. Fix. Arch. Eisenhuflemies.. 32 (4), 209-212 (1961).

4. M. Iwase. H. Fuiiwara, E. Ichise and N. Yamada, Steel Reseurch. 58 (5), 215-219 (1987).

5. M. Iwase. N. Yamada, K. Nishida and E. Ichise, Transactions of the Iron and Steel Socien of A.I.M.E., 4. 69-75 (1984).

6. Japanese Industrial Standards. $/ I S-H-/ 2+1$. Method for (hemical Analysis of Phosphorus in Bronze, 1977.

7. M. Iwase, E. Ichise, M. Takeuchi and T. Yamasaki, Transaction of Japan Instinte of Metuls, 25, 43-52 (1984).

8. M. Iwase. M. Yasuda and T. Mori. Electrochimica Ac/a. 19,261-266 (1979).

9. M. Iwase, E. Ichise and N. Yamada. Steel Research. 56 (6), 319-326 (1985).

10. E. T. Turkdogan and J. Pearson, Journal. Iron. Steel. Inst., 175, 393-401 (1953). 